\title{
THE CYTOTOXICITY EFFECT OF SPERMIDINE -SULPHUR ANALOGUES TYPE 1 (SSA-1) AND TYPE 2 (SSA-2) AGAINST HUMAN LUNG ADENOCARCINOMA CELLS (A549), HUMAN COLORECTAL ADENOCARCINOMA CELLS (HCT-8), AND HUMAN BREAST ADENOCARCINOMA CELLS (MCF-7)
}

\author{
Masnizahani binti Jamil ${ }^{1}$, Radiah Abdul Ghani ${ }^{1}$, Adzly Hairee Sahabudin ${ }^{1}$ and Fiona How \\ Ni Fong ${ }^{2}$ \\ ${ }^{1}$ Department of Biomedical Science, Kulliyyah of Allied Health Sciences, International \\ Islamic University Malaysia, Kuantan, Pahang, Malaysia, ${ }^{2}$ Department of Chemistry, \\ Kulliyyah of Science, International Islamic University Malaysia, Kuantan, Pahang, \\ Malaysia.
}

Presenter: Masnizahani binti Jamil, hannyjamil93@gmail.com

Introduction: Over accumulation of polyamines is one of the causes of cancer because polyamines could promote the cancer cells growth. Due to the lack of specificity and increased reports of side effects in the current cancer treatment, one of the strategies to overcome the challenges is by utilizing polyamines as vectors of known cytotoxic compounds to target the cancer cells. Therefore, this study was aimed to investigate the cytotoxicity effect of Spermidine Sulphur Analogues Type 1 and Type 2 (SSA-1 and SSA-2) against human lung adenocarcinoma cells (A549), human colorectal adenocarcinoma cells (HCT-8) and human breast adenocarcinoma cell (MCF-7).

Materials and method: The cytotoxicity studies of SSA-1 and SSA-2 against in vitro cells: A549, HCT-8, and MCF-7 were carried out by using MTT assay and the $\mathrm{IC}_{50}$ in each cell was determined.

Results: SSA-1 exhibited cytotoxicity effect in all selected cell lines with $\mathrm{IC}_{50}$ between $2.0 \mathrm{mM}$ to $5.3 \mathrm{mM}$. While SSA-2 also exhibited cytotoxicity effect in all cell lines with $\mathrm{IC}_{50}$ between $0.8 \mathrm{mM}$ to $5.0 \mathrm{mM}$.

Conclusion: SSA-1 and SSA-2 were cytotoxic against A549, HCT-8, and MCF-7. However, the cytotoxic effect was not potent against these cell lines as a higher concentration of compounds was needed to inhibit the cells growth. Hence, it is suggested that further study on the cytotoxicity effect of SSA-1 and SSA-2 in other cell lines should be conducted and the formulation of the analogues based on sulphur should be amended by conjugating it with selected metal. 